\title{
PENGARUH MODEL PEMBELAJARAN TEAM GAMES TOURNAMENT TERHADAP BERPIKIR KREATIF DAN HASIL BELAJAR SISWA PADA MATA PELAJARAN IPA KELAS V SD AL- ISLAH SURABAYA
}

\author{
Nurul Khikmawati, Thamrin Hidayat \\ Universitas Nahdlatul Ulama Surabaya \\ Ee-mail: nrlkhikmawati04@gmail.com
}

\begin{abstract}
Abstrak: Penelitian ini bertujuan untuk meningkatkan berpikir kreatif siswa pada mata pelajaran IPA melalui penggunaan model pembelajaran Team Games Tournament pada siswa kelas V-A SD Al-Islah Surabaya. Penelitian ini termasuk penelitian deskriptif kuantitatif dengan menggunakan metode eksperimen. Untuk desain penelitiannya yaitu One Group Pretest-Posttest. Di dalam penelitian ini pembelajaran dilakukan dalam satu kali pertemuan dengan waktu 4x35 menit. Teknik pengumpulan data menggunakan pretest dan posttest. Untuk menentukan perangkat pembelajaran layak digunakan atau tidak, maka perangkat pembelajaran dilakukan validasi oleh pakar kemudian didapatkan hasil yang akan dihitung menggunakan percentage of aggremant. Adapun teknik analisis data yang digunakan adalah Uji t-test yang digunakan untuk melihat seberapa besar pengaruh "'model pembelajaran Team Games Tournament terhadap berpikir kreatif dan hasil belajar siswa. Hasil penelitian ini menunjukkan bahwa model pembelajaran Team Games Tournament terhadap berpikir kreatif siswa diperoleh nilai correlation (nilai korelasi) sebesar 0.659 artinya memiliki hubungan kuat dan positif atau sangat berpengaruh terhadap berpikir kreatif siswa. Sedangkan untuk nilai correlation (nilai korelasi) hasil belajar (kognitif) siswa sebesar 0.756, artinya model pembelajaran Team Games Tournament memiliki hubungan kuat dan positif atau sangat berpengaruh terhadap hasil belajar (kognitif) siswa. Sehingga dari penelitian ini dapat di ambil simpulan bahwa model pembelajaran Team Games Tournament dapat mempengaruhi berpikir kreatif dan hasil belajar (kognitif) siswa.
\end{abstract}

Kata Kunci : Model Pembelajaran Team Games Tournament, Berpikir Kreatif, Hasil Belajar

\begin{abstract}
This study aims to improve students' creative thinking in science subjects through the use of Team Games Tournament learning models in V-A grade students at Al-Islah Elementary School Surabaya. This study included quantitative descriptive research using the experimental method. For the design of the study, the One Group Pretest-Posttest. In this study the learning was conducted in one meeting with $4 \times 35$ minutes. Data collection techniques using pretest and posttest. To determine whether the learning device is worth using or not, then the learning device is validated by experts and the results are calculated which will be calculated using a percentage of aggregation. The data analysis technique used is the t-test test which is used to see how much influence the Team Games Tournament learning model has on creative thinking and student learning outcomes. The results of this study indicate that the Team Games Tournament learning model of students 'creative thinking is obtained correlation value (correlation value) of 0.659 meaning having a strong and
\end{abstract}


positive relationship or very influential on students' creative thinking. While for the correlation value (correlation value) of student learning outcomes (cognitive) of 0.756, it means that the Team Games Tournament learning model has a strong and positive relationship or is very influential on student (cognitive) learning outcomes. So that this research can be concluded that the Team Games Tournament learning model can influence creative thinking and student (cognitive) learning outcomes.

Keyword: Model of Team Games Tournament Learning, Creative Thinking, Learning Outcomes

\section{PENDAHULUAN}

Menurut (Priansa, 2017:310) model pembelajaran koperatif tipe Team Games Tournament (TGT) merupakan pembelajaran yang mengandung unsur formasi, instruksi dan lembar tugas. Adapun sintaks dalam model pembelajaran Team Games Tournament (Trianto,2007) adalah guru menyampaikan tujuan pembelajaran, materi yang akan disampaikan dam kegiatan apa saja yang akan dilakukan atau bisa di sebut dengan (class presentation), belajar kelompok atau disebut dengan teams dimana dalam belajar kelompok anggota kelompok satu dengan yang lainnya saling berdiskusi tentang materi yang di pelajari, setelah itu dilanjutkan dengan permainan atau game. Dalam game ini guru bisa mengkonsep materi menjadi suatu permainan sehingga siswa bisa merasakan belajar sambil bermain. Dilanjutkan dengan pertandingan (tournaments) yang akan di adakan agar antar kelompok bisa bertanding secara sehat dan anggota kelompok juga pastinya akan besaingan juga untuk mendapatkan skor maksimal. Di akhir pembelajaran akan ada pemberian penghargaan kepada kelompok (team recognition) terbaik.
Jadi Team Games Tournament adalah model pembelajaran kooperatif yang dapat diterapkan di kelas tingkatan tinggi termasuk kelas 5 karena akan melibatkkan aktivitas seluruh siswa tanpa membedakan suku, ras dan agama. Model pembelajaran TGT ini bisa juga dikatakan sebagai model pembelajaran yang dapat dilakukan siswa belajar sambil bermain. Karena mereka juga dilatih untuk bersaing secara sehat di dalam kompetisi. Sehingga model ini sangat tepat digunakan karena terjadi diskusi kelas yang optimal dan bermakna. Dengan penerapan model pembelajaran ini, kemampuan mereka dalam mengkonstruksi serta kemampuan berpikir kreatif akan muncul dengan adanya penerapan melalui model pembelajaran yang sesuai dengan materi yang di pelajari.

Berbicara tentang kreatif pastinya kata kreatif tidak asing di dalam dunia Pendidikan dn pastinya ada kaitannya dengan berpikir kreatif seorang siswa. Hoerce B.Dan Ave dalam jurnal (Rahayu, 2018) menjelaskan bahwa kreativitas adalah suatu hal untuk menciptakan ide baru, gagagasan baru, model atau bentuk baru yang di dalamya terdapat unsur keindahan. Menurut Carin dan Sund 
(dalam Susanto, 2013:106) semua orang yang memiliki kekreatifan pasti mereka memiliki karakteristik yang unik. Seperti mereka memiliki rasa ingin tahu yang sangat luar biasa dengan banyak bertanya, mempunyai banyak ide baru, dengan ide barunya ia memiliki keinginan yang luar biasa untuk mencari tau dan menciptakan hal yang baru, dan pastinya orang yang kreatif mereka akan memilih pekerjaan yang justru mereka anggap sulit karena itu akan menjadi sebuah tantangan dan mempunyai pengetahuan luas.

Menurut Susanto, (2013:114) ada empat alasan pentingnya belajar kreatif diantaranya adalah, 1) belajar kreatif dapat membantu anak untu menghasilkan sesuatu yang berguna dan mereka tidak bergantung pada orang lain, 2) belajar kreatif dapat membantu kita untuk mencari solusi terkait dengan masalah yang kita hadapi di masa sekarang atau masa yang akan datang, 3) belajar kreatif memberikan manfaat yang luar biasa di dalam kehidupan kita dan bisa jadi dapat megubah karier kita jauh lebih baik dengan adanya kreatifitas yang kita miliki sehingga bisa menunjang kehidupan kita.

Berdasarkan uraian di atas terkait dengan pentingnya berpikir kreatif, dari hasil observasi menunjukkan bahwa masih kurangnya guru menerapkan model pembelajaran TGT dan berujung kurangnya memahami sintaks dari model pembelajaran termasuk model pembelajaran Team Games Tournament. Masih banyak ditemukan model pembelajaran yang diterapkan masih menggunakan model pembelajaran konvensional (ceramah). Dengan adanya permasalahan tersebut mengakibatkan hasil berpikir kreatif dan hasil belajar (kognitif) siswa masih kurang memuaskan. Karena di dalam proses pembelajaran yang berperan adalah guru dalam menentukan model pembelajaran yang sesuai dengan materi yang disampaikan.

Berdasarkan uraian dan beberapa permasalahan telah dikemukakan, maka peneliti mengajukan rumusan masalah dalam penelitian ini adalah "Bagaimana pengaruh model pembelajaran Team Games Tournament terhadap berpikir kreatif dan hasil belajar (kognitif) siswa pada mata pelajaran IPA kelas V SD AlIslah Surabaya"

\section{KAJIAN PUSTAKA}

Menurut (Ngalimun, 2016:234) model pembelajaran Team Games Tournament (TGT) pada dasarnya dirancang agar peserta didik mampu melaksanakan proses pembelajaran dengan kompetisi secara sehat, bertanggung jawab serta keterlibatan aktif peserta didik dalam proses belajar.

Ketika menerapkan model pembelajaran ini siswa di bagi menjadi beberapa kelompok yang masing-masing kelompok beranggotakan 4-5 orang, masing-masing kelompok bisa diberikan tugas yang sama atau berbeda. Setelah masing-masing kelompok sudah terbentuk dan diberiak tugas oleh gurunya mereka mempunyai tanggung jawab untuk mendiskusikan tugas tersebut dan di usahakan antar anggota satu dengan lainnya yang ada di dalam kelompok tersebut saling memberikan pemahaman materi terkait tugas yang belum dimengerti oleh salah satu anggota kelompok. Dengan adanya kelompok- 
kelompok yang telah di bentuk guru berharap agar masing-masing anggota memiliki rasa kompetisi yang luar biasa sehingga diskusi antar kelompok juga berjalan dengan baik dan kompak. Apabila salah satu anggota kelompok yang kurang memahami materi tugasnya siswa yang lainnya dengan bantuan guru akan memberikan pemahaman dengan penyampaian yang ramah, terbuka sehingga siswa pun juga merasa senang selama diskusi. Setelah kerja kelompok selesai, setiap kelompok mempresentasikan hasil dari diskusi kelompok yang akan diwakili oleh masing-masing kelompok dan membuka sesi tanya jawab. Dari situlah terjadi diskusi kelas. Jika ada waktu lebih setelah UAS Team Games Tournament bisa dilaksanakan dalam beberapa pertemuan agar waktu tersebut bisa bermanfaat.

Dalam pembelajaran TGT ini siswa dilatih untuk mengkonstruksi sendiri dari materi yang mereka dapatkan selama pembelajaran. Sehingga dengan kemampuan mengkonstruksi, berpikir kreatif siswa akan muncul. Salah satunya pada materi rantai makanan yang akan digunakan sebagai salah satu materi penelitian. Dalam proses pembelajaran ini siswa di biasakan untuk dapat berpikir kreatif. Karena berpikir kreatif bisa dikatakan memiliki nilai lebih dibandingkan siswa yang hanya memiliki kemampuan berpikir kritis saja. Karena mengapa berpikir kritis itu dapat menjawab permasalahan yang hanya dihadapinya saja di waktu itu, sedangkan berpikir kreatif mampu memperkaya cara berpikir dengan cara beragam dan segi apapun di masa sekarang atau masa yang akan datang.
Kreativitas bisa dikatakan muncul secara tiba-tiba ketika melihat suatu benda atau kejadian yang di awali dengan rasa ingin tahu yang besar sebelum ideide baru itu muncul dan menjadi suatu hal yang baru. Jadi bisa di simpulkan bahwa berpikir kreatif adalah kemampuan untuk menciptakan hal yang baru yang sebelumnya tidak ada menjadi ada, atau yang sebelumnya sudah ada di konstruksi menjadi hal yang luar biasa dari hasil interaksi di lingkungan yang muncul secara tiba-tiba. Jadi berpikir kreatif bisa dikatakan tidak selalu menghasilkan sesuatu yang benar-benar baru tetapi kemampuan untuk menjadikan sesuatu yang ia temukan menjadi hal yang lebih sempurna dan luar biasa. Komponen berpikir kreatif, menurut Munandar (1999) dalam (Susanto, 2013, p. 111) meliputi berpikir lancar (fluency), berpikir luwes, (flexibility), berpikir orisinil (originality), keterampilan memerinci (elaboration).

Seorang siswa selain harus memiliki kemampuan berpikir kreatif, tentunya hasil belajar yang memuaskan adalah harapan seorang guru. Karena siswa yang memiliki kemampuan berpikir kreatif belum tentu hasil belajar nya memuaskan pula, begitupun sebaliknya seorang siswa yang meiliki hasil belajar memuaskan belum tentu berpikir kreatifnya maksimal. Hasil belajar menurut Gagne \& Briggs (1979:51) dalam (Suprihatiningrum, 2017) adalah kemampuan yang dimiliki siswa dari hasil yang akan siswa dapatkan selama belajar dan dapat diamati melalui kebiasaan siswa dalam belajar (learner's performance). Dalam dunia pendidikan, ada beberapa macam tipe hasil belajar 
yang telah dikemukakan oleh para ahli antara lain Gagne (1979:51) mengemukakan lima tipe hasil belajar, yaitu keterampilan intelektual, strategi kognitif, informasi verbal,keterampilan motorik, dan sikap.

\section{METODE}

Penelitian ini dilakukan di SD AlIslah Surabaya kelas $\mathrm{V}$ semester gasal tahun pelajaran 2018-2019. Sampel dalam penelitian ini adalah dilakukan dengan cara pengambilan secara acak atau random dari beberapa kelas yang ada. Sehingga dari hasil random terpilih kelas V-A dengan jumlah siswa 42 yang merupakan sampel dari penelitian ini yang akan digunakan sebagai kelas uji coba. Variabel dependen (variabel terikat) dalam penelitian ini adalah kemampuan berpikir kreatif dan hasil belajar (kognitif) siswa. Indikator berpikir kreatif sendiri meliputi kefasihan (fluency) adalah kemampuan mengeluarkan ide atau gagasan-gagasan sebanyak-banyaknya dengan jelas. Seperti siswa banyak mengajukan pertanyaan, banyak bertanya, banyak menjawab pertanyaan dengan tepat. Keluwesan (fleksibility) adalah kemampuan untuk mengeluarkan banyak ide atau gagasan tentunya dari beberapa pandangan dan lebih dari satu ide yang di ungkapkan. Originalitas (originality) adalah kemampuan untuk mengeluarkan ide atau gagasan yang unik, misalnya berbed dari yang ada sebelumnya. Seperti mungkin gelas saat ini berbektuk tabung dengan ide yang ada bentuk tabung itu di ubah menjadi bentuk segitiga atau lainnya dan keterampilan memerinci (elaboration). Adapun variabel independen (variabel bebas) dalam penelitian ini adalah penerapan model pembelajaran Team Games Tournament pada mata pelajaran IPA materi rantai makanan kelas V SD Al- Islah Surabaya.

Adapun data penelitian ini di peroleh dari lembar tes yang berisi pertanyaanpertanyaan yang berhubungan dengan materi rantai makanan. Lembar tes ada dua macam yaitu Pretest dan Posttest. Hasil berupa nilai dan kedua nilai akan dibandingkan ketuntasannya. Ketuntasan didasarkan pada interpretasi kemampuan berpikir kreatif dan nilai hasil belajar. Instrumen yang diberikan berupa lembar berisi 5 soal uraian yang akan digunakan untuk mengetahui hasil berpikir kreatif dan hasil belajar siswa. Soal uraian, penilaiannya menggunakan rubrik agar setiap soal dapat ditentukan nilai yang sama atau mendekati kesamaan dalam penilaian.

Pada penelitian ini teknik analisa data yang digunakan adalah uji t-test untuk sampel korelasi data rasio sehingga untuk menjawab rumusan masalah apakah ada pengaruh atau tidak dari model pembelajaran Team Games Tournament yang diberikan terhadap berpikir kreatif dan hasil belajar (kognitif) siswa. Sehingga data yang diperoleh berdistribusi normal dan homogen dengan menggunakan analisis komparatif uji statistik Paired Sample ttest.

\section{HASIL DAN PEMBAHASAN}

Salah satu cara untuk meningkatkan berpikir kreatif siswa adalah dengan cara menerapkan model pembelajaran yang bervariasi dan pastinya disesuaikan dengan materi yang diajarkan. Sehingga 
penelitian ini menggunakan model pembelajaran Team Games Tournament. Penelitian ini melibatkan satu kelas di SD Al-Islah Surabaya kelas V-A dengan jumlah 41 siswa sebagai kelas uji coba yang akan diterapkan model pembelajaran Team Games Tournament. Berdasarkan nilai pretest dan posttest berpikir kreatif siswa diperoleh nilai correlation (nilai korelasi) sebesar 0.659 artinya memiliki hubungan kuat dan positif atau sangat berpengaruh. Sedangkan tingkat signifikansi hubungan hasilnya 0.000 artinya signifikan pada level 0.01 dan degree of freedom (derajat kebebasan) untuk analisis t-paired selalu $\mathrm{N}-1$, di mana $\mathrm{N}$ adalah jumlah sampel. Sehingga Sig. (2-tailed) atau lebih dikenal dengan nilai probabilitas / pvalue uji t-paired menunjukkan hasil 0.000 artinya ada perbedaan sebelum dan setelah perlakuan, sebab nilai $\mathrm{p}$ value < 0.05 . sehingga dapat disimpulkan bahwa ada pengaruh model pembelajaran Team Games Tournament terhadap berpikir kreatif siswa.

Menurut Casdan dan Welsh dalam (Supriadi, 2001) dalam penelitiannya menemukan bahwa siswa yang memiliki kreativitas tinggi kebanyakan dari mereka menjadi orang yang mandiri, berusaha untuk menciptakan ide-ide kreatif dan memiliki banyak relasi, lebih terbuka dan aktif.

Upaya untuk meningkatkan hasil belajar (kognitif) siswa agar lebih maksimal dengan cara tidak menerapkan model pembelajaran konvensional dan pastinya disesuaikan dengan materi yang diajarkan. Sehingga penelitian ini menggunakan model pembelajaran Team
Games Tournament untuk memenuhi analisis materi yang ada.

Berdasarkan nilai pretest dan posttest hasil belajar kognitif siswa diperoleh correlation (nilai korelasi) sebesar 0.756 artinya memiliki hubungan kuat dan positif atau sangat berpengaruh model pembelajaran yang diberikan. Sedangkan tingkat signifikansi hubungan hasilnya 0.000 artinya signifikan pada level 0.01 dan degree of freedom (derajat kebebasan) untuk analisis t-paired selalu $\mathrm{N}-1$ dimana $\mathrm{N}$ adalah jumlah sampel. Sehingga Sig. (2-tailed) atau lebih dikenal dengan nilai probabilitas / pvalue uji t-paired menunjukkan hasil 0.000 artinya ada perbedaan sebelum dan setelah perlakuan, sebab nilai $\mathrm{p}$ value < 0.05 . Sehingga dapat disimpulkan bahwa ada pengaruh model pembelajaran Team Games Tournament terhadap hasil belajar (kognitif) siswa. Dari hasil tersebut menunjukkan bahwa hasil belajar (kognitif) siswa merupakan hasil dari suatu proses pembelajaran yang di dalamnya terdapat faktor-faktor untuk memepengaruhi, baik faktor internal maupun eksternal.

Tinggi rendahnya hasil belajar seseorang menurut (Ruseffendy, 2015) dipengaruhi oleh faktor- faktor yang mempengaruhi hasil belajar. Ada 10 macam faktor yang bisa mempengaruhi hasil belajar yaitu kecerdasan, kesiapan anak saat belajar, bakat anak yang dimiliki, kemauan untuk belajar, minat anak, model penyajian materi yang disiapkan oleh guru, pribadi dan sikap guru, suasana belajar, kompetensi guru dan keadaan lingkungan. Sehingga simpulan dari hasil dan pembahasan di atas terdapat pengaruh model 
pembelajaran Team Games Tournament terhadap berpikir kreatif dan hasil belajar (kognitif) siswa.

\section{SIMPULAN}

Berdasarkan hasil penelitian yang telah dilakukan simpulan dari penelitian ini adalah:

a. Keterlaksanaan model pembelajaran Team Games Tournament terlaksana dengan baik

b. Berpikir kreatif siswa sebelum menggunakan model pembelajaran Team Games Tournament dari hasil prestest memberikan kategori nilai sangat kurang baik

c. Berpikir kreatif siswa setelah menggunakan model pembelajaran Team Games Tournament dari hasil posttest memberikan kategori nilai baik

d. Hasil belajar (kognitif) siswa sebelum menggunakan model pembelajaran Team Games Tournament dari hasil prestest memberikan kategori nilai sangat kurang baik

e. Hasil belajar (kognitif) siswa setelah menggunakan model pembelajaran Team Games Tournament dari hasil posttest memberikan kategori nilai baik

f. Model pembelajaran Team Games Tournament berpengaruh terhadap berpikir kreatif siswa kelas V-A SD Al-Islah Surabaya

g. Model pembelajaran Team Games Tournament berpengaruh terhadap hasil belajar (kognitif) siswa kelas VA SD Al-Islah Surabaya

\section{SARAN}

Sesuai dengan kesimpulan hasil penelitian, maka dapat disampaikan saran-saran:

a. Guru sebagai fasilitator bagi siswa hendaknya dapat mempersiapkan rencana pembelajaran yang sesuai antara materi pembelajaran dengan model dan metode pembelajaran yang akan diterapkan sehingga dapat di aplikasikan sesuai dengan sintaks pembelajaran yang digunakan. Selain itu tentunya juga harus disesuaikan dengan fasilitas pembelajaran yang ada sehingga pembelajaran tidak terkesan membosankan.

b. Guru sebaiknya mendorong siswa ikut serta berperan aktif dalam proses pembelajaran dengan memperhatikan petunjuk guru saat di dalam kelas maupun di luar kelas dan selalu mengerjakan tugas yang telah diberikan oleh guru agar memperoleh nilai yang maksimal.

\section{DAFTAR PUSTAKA}

Amiruddin. (2016). Perencanaan Pembelajaran (Konsep dan Implementasi). Yogyakarta: Parama Ilmu.

Anas, S. (2009). Pengantar Statistik Pendidikan. Jakarta: Rajawali Pers.

Andianti, Y. P. (2013). Penerapan Metode Inkuiri untuk meningkatkan aktivitas dan Hasil Belajar IPS pada Siswa Kelas 5 SD Negeri Salatiga 08 Kecamatan Sidorejo Semester 2 Tahun Pelajaran 2012/2013. Salatiga . 
Arikuntoro, S. (2002). Dasar-dasar Evaluasi Pendidikan . Jakarta: Rineka Cipta.

Arikuntoro, S. (2006). Prosedur Penelitian Suatu Pendekatan Praktik. Jakarta : Rineka Cipta.

Arikuntoro, S. (2010). Prosedur Penelitian Suatu Pendekatan Praktik. Jakarta: PT Rineka Cipta.

Arikuntoro, S. (2013). Prosedur Penelitian Suatu Pendekatan Praktik. Jakarta: Rineka Cipta.

Borich, G. D. (1994). Observation Skills for Effective Teaching. USA: The University of Texas.

Depdiknas. (2004). Pedoman Penyusunan Lembar Kegiatan Siswa dan Skenario Pembelajaran. Direktorat Jenderal Pendidikan Dasar dan Menengah .

Eko, W. P. (2007). Evaluasi Program Pembelajaran. Yogyakarta: Pustaka Belajar.

Ernawati, D., Putra, A., \& Suadnyana. (n.d.). Pengaruh Penerapan Model Kooperatif Tipe Team Games Tournament Terhadap Hasil Belajar IPA Siswa Kelas IV SDN6 Mengwi, Bandung.

Hadi, A., Nor, B., \& Agustina P, M. (2016). Pengaruh Kompetensi Pedagogik Guru Terhadap Belajar Siswa Pada Mata Pelajaran Ekonomi Kelas X di SMAN 1 Danau Panggang. Jurnal Pendidikan Ekonomi, Cangkal , 4.

Huda, M. (2016). Model-model Pengajaran dan Pembelajaran. Yogyakarta: Pustaka Belajar.
Ibrahim, M. (2010). Dasar-dasar Proses Belajar Mengajar. Surabaya: Unesa UniversityPress.

Komara, E. (2014). Belajar dan Pembelajaran Interaktif. Bandung: PT Refika Aditama.

Maolani, R. A., \& Cahyana, U. (2015). Metodologi Penelitian Pendidikan. Jakarta: Rajawali Pers.

Ngalimun. (2016). Strategi dan Model Pembelajaran. Yogyakarta: Aswaja Pressindo.

Ngalimun. (2017). Strategi Pembelajaran. Yogyakarta: Dua Satria Offet.

Permatasari, N. E. (2017). Peningkatan Hasil Belajar IPA Siswa Kelas 5 SD Menggunakan Model Pembelajaran Kooperatif Tipe TGT. JPSD vol 3 No 2 , 96-104.

Permendikbud. (2016). Standart Proses Pendidikan Dasar dan Menengah Tentang perencanaan Pembelajaran. 5.

Priansa, D. J. (2017). Pengembangan Strategi dan Model Pembelajaran. Bandung: CV Pustaka Setia.

Purwanto. (2008). Metodologi Penelitian Kuantitaif. Yogyakarta: Pustaka Pelajar.

Purwanto, N. (2000). Psikologi Pendidikan. Bandung: Remaja Rosdakarya.

Purwati, Dwijananti, P., \& Mosik. (2013). Implementasi Team Games Tournament Berbasis Percobaan Fisika Terhadap Kemampuan Berpikir Kreatif dan Hasil Belajar Peserta didik. UPEJ 2 (1) . 
Rahayu, D. W. (2018). Penerapan Model Pembelajaran Langsung Untuk Meningkatkan Kreativitas Anak Sekolah Dasar. Proceedings of The ICECRS , 138.

Riduwan. (2007). Skala Pengukuran Vriabel-Variabel Penelitian. Bandung: Alfabeta.

Ruseffendy, E. T. (2015). Dasar-dasar Penelitian Pendidikan. Bandung: IKIP Bandung Press.

Samatowo, U. (2010). Pembelajaran IPA di Sekolah Dasar. Jakarta: Indeks.

Sanjaya, W. (2005). Strategi Pembelajaran Berbasis Standar Proses Pendidikan. Bandung: Alfabeta.

Shoimin. (2014). Strategi dan Model Pembelajaran. Bandung: Cipta Rekasa.

Sudarmi, M. Y., Suwatra, W., \& Suarjana, M. (2014). Penerapan Model Pembelajaran Kooperatif Tipe Teams Games Tournament untuk Meningkatkan Hasil Belajar Pendidikan Kewarganegaran. e-Journal MIMBAR PGSD UNIVERSITAS PENDIDIKAN GANESHA , 3.

Sugiono. (2005). Statistika untuk Penelitian . Bandung: CV Alfabeta.

Sugiyono. (2017). Metode Penelitian Kuantitatif, Kualitatif dan $R \&$ $D$. Bandung: Alfabeta.

Sugiyono. (2015). Metode Penelitian Pendidikan. Bandung: Alfabeta.

Suharsaputra, U. (2012). Metode Penelitian Kuantitatif, Kualitatif dan Tindakan. Bandung: PT Refika Aditama.
Sumantri, M. S. (2015). Strategi

Pembelajaran Teori dan Praktik di Tingkat Pendidikan Dasar. Jakarta: Rajawali Pers.

Supriadi, D. (2001). Kreativitas, Kebudayaan dan Perkembangan Iptek. Bandung: Alfabeta.

Suprihatiningrum, J. (2017). Strategi Pembelajaran Teori dan Aplikasi. Yogyakarta: Ar-Ruzz Media.

Susanto, A. (2013). Teori Belajar dan Pembelajaran di Sekolah Dasar. Jakarta: Fajar Interpratama Mandiri.

Taufiq, M., \& Chatib, M. (2018). Pentingnya Implementasi Pembelajaran Literasi Sains Untuk Meningkatkan Kemampuan Berpikir Kritis Siswa SMP di Pondok Pesantren Salafiyah "Cokrokertopati" Kabupaten Magetan. Jurnal Unusa, 108.

Trianto. (2009). Mendesain Model Pembelajaran Inovatif Progresif. Jakarta: Kencana Prenada Media Group.

Trianto. (2007). Model-model Pembelajaran Inovatif Berorientasi Konstruktivistik . Jakarta: Prestasi Pustaka. 